\title{
THE EFFECT OF THE COMBINATION ADDITIVE ADMIXTURES TO INCREASE SETTING TIME AND COMPRESSIVE STRENGTH AT THE CONCRETE CASTING IN WARM TROPICAL TEMPERATURE
}

\author{
Tamrin *, Mardewi Jammal \\ Department of Civil Engineering, Mulawarman University, Samarinda, Indonesia
}

\author{
Juli Nurdiana \\ Department of Environmental Engineering, \\ Mulawarman University, Samarinda, Indonesia \\ Amirul Mirza Ghulam \\ Nusa Konstruksi Engineering Inc, Jakarta, Indonesia \\ *Corresponding Author: fts_tamrin@yahoo.com
}

\begin{abstract}
Every time in casting's concrete in warmer tropical temperatures, concrete setting time is needed to support the concrete's workability. The concrete casting needs an additional setting time by adding silica fume (SF), fly ash (FA), or add other materials. This study attempts to use Coca-Cola as the supporting material to determine the setting time of concrete by combining Coca-Cola and Plastocrete ${ }^{\circledR}$ RT6 plus, which are done to show the improved setting time and concrete compressive strength. This idea began with the concept of sugar content in Coca-Cola, which is very high, and plastocrete ${ }^{\circledR}$ RT6 plus is an additional ingredient to increase setting time and concrete compressive strength. The authors are inspired to take both of the benefits of these ingredients by combining the Plastocrete ${ }^{\circledR}$ RT6 plus $0.35 \%$ and Coca-Cola $0.15 \%$ from total weight of the cement and reducing the amount of cement used by $11 \%$. The results of the combination revealed the setting time of concrete increased by $54.6 \%$ longer than normal concrete with less usage of cement and increasing the concrete compressive strength by 1,6\%. If the amount of the cement in concrete mix is not reduced, the concrete compressive strength is 3.2\% higher than the normal concrete. Subsequently, the addition of those materials is not only to delay the concrete setting time but they are also significantly increasing the concrete compressive strength, and become the alternative to decrease cement usage. The highlights are the additional materials as a problem solver for concrete casting in tropical areas and a few areas that needed a
\end{abstract}


longer setting time. This method has been implemented in some building construction of Mulawarman University, Samarinda, Indonesia

Keywords: Concrete setting time; Coca-Cola; silica fume; fly ash; Plastocrete ${ }^{\circledR}$ RT6

Cite this Article: Tamrin, Mardewi Jamal, Juli Nurdiana and Amirul Mirza Ghulam, The Effect of the Combination Additive Admixtures to Increase Setting Time and Compressive Strength at the Concrete Casting in Warm Tropical Temperature, International Journal of Civil Engineering and Technology, 11(4), 2020, pp. 61-72

https://iaeme.com/Home/issue/IJCIET?Volume=11\&Issue=4

\section{INTRODUCTION}

Concrete is a material used as the main structure in building construction and in the implementation of concrete casting, it is necessary to take special action if have a problem at certain conditions including hot weather conditions, as an example like when sending the concrete to the casting location in hot weather and so on. To reduce the risk of decreasing the compressive strength of concrete which is caused by the delay of concrete material arriving at the location, so the setting time delay is done by adding additional materials, such as silica fume (SF), fly ash (FA), or other additional materials, which target to delay setting time [1, 6-14].

Knowledge of concrete setting time is indeed very crucial for a job that relates to constructions, that matter can help engineers to make decisions at various stages of implementation, such as transporting concretes in a huge amount of quantities. Furthermore, technical issues related to mixing and casting concrete where need to be analyzed properly, as research conducted by the Japan Concrete Institute (JCI) where the study examines about the handling of shrinkage in concrete, and the results show that shrinkage in concrete can cause cracks on concrete surfaces [3], so concrete casting in special conditions, it is necessary to manage the concrete setting time properly to avoid excessive dehydration of concrete.that's why it necessary observed concrete shrinkage when the time setting is in progress [4], concrete time settings are determined by the condition where the casting takes place, such as water ratio, temperature, the concentration of additives, mixing type, and cement composition [519].

The results of previous studies indicate that sugar can increase the concrete setting time [26]. While, it is known that Coca-Cola or Coke is a popular, widely available beverage and after being investigated, it contains high sugar levels of $10.6 \mathrm{~g}$ per 100 $\mathrm{mL}$ [27], based on that information, it can be used as additional material to delay the concrete's setting time, but until now, it has not been investigated in a more particular way about increasing the concrete setting time and its effect on the compressive strength of concrete. It is important to remember that concrete casting in a warmer tropical area or a hot rural area needs a special treatment, especially for the concrete mixtures so that the slump value can be maintained properly. In some cases, the addition of SF, FA, and Plastrocrete ${ }^{\circledR}$ RT 6 Plus is not a new material anymore, where the addition of the material used to delay setting time and does not reduce the quality of concrete.

Plastocrete ${ }^{\circledR}$ RT6 plus is introduced as additional material in Indonesia around 2016 as a new type of additional material with the main advantages of increasing concrete setting time, improving workability, and improving concrete quality, which is suitable in tropical countries, such as Indonesia [25]. However, it is the prominent reason of this study uses the combination of Plastocrete® RT6 plus and Coca-Cola as the additional materials. It aims to delay the setting time, increase the compressive 
strength of concrete, and reduce the amount of cement used. This study develops into the previous studies that used SF and FA which only examined the timing of the setting [2].

This study aims to examine the combination of Coca-Cola and Plastocrete ${ }^{\circledR}$ RT6 plus as additional material for concrete. Thus, combining the two materials can reduce cement use and delay the concrete's setting time, this has been applied in some special conditions during the building's construction at Mulawarman University, which requires the concrete's setting time delay and reduce excessive losses due to uncontrolled use of cement.

\section{METHODOLOGY}

\subsection{Material}

All material sample that testing, done in Laboratory of Engineering Faculty of Mulawarman University in April 2019

\subsubsection{The materials Coarse Aggregate and Fine Aggregate}

The study used the coarse aggregate and fine aggregate that is originated from Palu, Central of Sulawesi, Indonesia because local material in Borneo can not support highquality concrete. The aggregate was tested according to ASTM C 33-92 standard [23], where the material being tested has met, the conditions under which the size of the material falls within the upper limits and lower limits specified in ASTM C 33-92, the result can be seen in Figure 1 below,

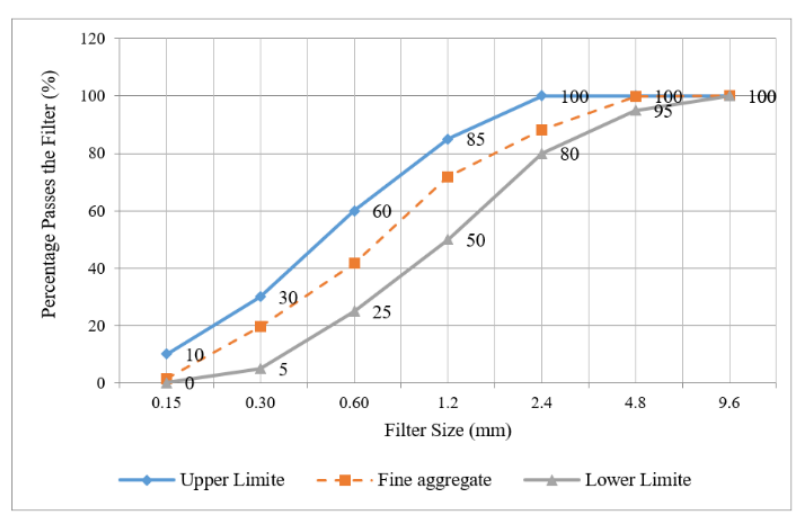

(a) Sand Aggregate

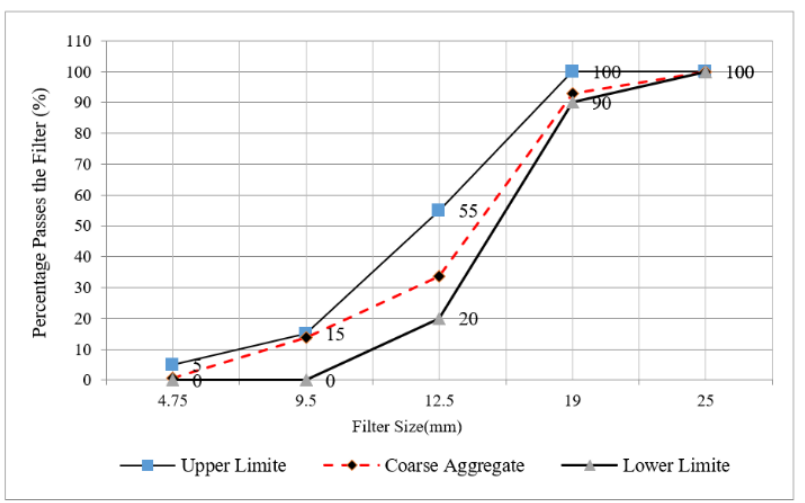

(b) Coarse Aggregate.

Figure 1 Aggregate size 


\subsubsection{Chemical and Physical Composition of Cementations Materials.}

The cement that is used in this study was an Ordinary Portland Cement (OPC), and the additional materials are Silica Fume (SF) and Fly Ash (FA) with the chemical composition and physical properties presented in Table 1, while other additives used were Coca-Cola and Plastocrete ${ }^{\circledR}$ RT6 plus, the composition of which can be seen in the brand of each product $[25,27]$

Table 1 Chemical and Physical Composition of Cementations Materials.

\begin{tabular}{|c|c|c|c|}
\hline Chemical & OPC & SF & FA \\
\hline $\mathrm{SiO} 2$ & 20,90 & 91,20 & 47,80 \\
\hline $\mathrm{A} 2 \mathrm{O} 3$ & 5,10 & 0,71 & 25,01 \\
\hline $\mathrm{Fe} 2 \mathrm{O} 3$ & 2,40 & 1,25 & 8,80 \\
\hline $\mathrm{MgO}$ & 4,00 & 1,73 & 0,90 \\
\hline $\mathrm{TiO} 2$ & - & - & 8,70 \\
\hline $\mathrm{CaO}$ & 64,01 & 0,45 & 8,70 \\
\hline $\mathrm{Na} 2 \mathrm{O}$ & 0,50 & 0.42 & 1,20 \\
\hline $\mathrm{K} 2 \mathrm{O}$ & - & 1,19 & 0,85 \\
\hline $\mathrm{SO} 3$ & 2,40 & - & 5,15 \\
\hline $\mathrm{LOI}$ & 2,40 & 1,18 & \\
\hline
\end{tabular}

$\mathrm{LOI}=$ loss on ignition

\subsection{Job Mix Design}

In this study, the concrete was designed with two different compressive strengths both the concrete strength f'c20 MPa and f'c25 MPa, thus, the design was made based on the American Concrete Institute (ACI 318-89) [31]. From the results of the Job Mix Design, it was obtained the composition of the material given in table 2 below.

Table 2 Job Mix Design f'c $20 \mathrm{MPa}$ and f'c $25 \mathrm{MPa}$

\begin{tabular}{|c|c|c|}
\hline Description & f'c20 MPa & ''c25 MPa \\
\hline Compressive strength & $20 \mathrm{MPa}$ & $25 \mathrm{MPa}$ \\
\hline $\begin{array}{c}\text { Targeted of average compressive strength of } \\
\text { the concrete (f'cr) }\end{array}$ & $32 \mathrm{MPa}$ & $37 \mathrm{MPa}$ \\
\hline Cement water factor & 0,59 & 0,5 \\
\hline Combined aggregate content & 1850 & 1730 \\
\hline Slump value & $120 \pm 5 \mathrm{~mm}$ & $120 \pm 5 \mathrm{~mm}$ \\
\hline Amount of water & $205 \mathrm{~kg} / \mathrm{m} 3$ & $205 \mathrm{~kg} / \mathrm{m} 3$ \\
\hline Amount of cement & $338,4 \mathrm{Kg} / \mathrm{m} 3$ & $455,6 \mathrm{Kg} / \mathrm{m} 3$ \\
\hline Fine aggregate content & $692 \mathrm{~kg} / \mathrm{m} 3$ & $622 \mathrm{~kg} / \mathrm{m} 3$ \\
\hline Coarse aggregate content & $1042 \mathrm{~kg} / \mathrm{m} 3$ & $1107,2 \mathrm{~kg} / \mathrm{m} 3$ \\
\hline
\end{tabular}

\subsection{Testing Procedure}

The concrete setting time test was determined by following ASTM C -403 [19], where the mortar was obtained by filtering fresh concrete through $5 \mathrm{~mm}$ sieve and the setting time was determined by testing the strength of the needle which penetrated a mortar of $25 \mathrm{~mm}$. In this experiment, the temperature variation of the test was carried out in an environment with a controlled temperature of around $27 \pm 5^{\circ} \mathrm{C}$. Furthermore, the initial and final settings were defined as the penetration time regulated by the provisions of ASTM C403 / C403M, where compressive strength 3.5 MPa or (500 Psi) is defined as the initial time setting, in this condition concrete has begun to experience binding mean while compressive strength of $27.6 \mathrm{MPa}$ or (4000Psi) is the final setting time where the 
concrete is hard and the penetration needle can no longer penetrate into the concrete $[18,29]$, meanwhile, for the Concrete Compressive Strength test, ASTM C39-86 is used with Standard specimens [30].

In this study also conducted measurement of the effect from additional material in concrete mixtures that tested on $\mathrm{f}^{\prime} \mathrm{c} 25 \mathrm{MPa}$, where the concrete mixtures added with Silica Fume (SF), Fly Ash (FA), Plastocrete® RT6plus, and Coca-Cola, that aims to compare the concrete setting time of each additional material. to result in record research precisely, this research uses the symbols like described in the following,

a. Normal concrete $\mathrm{f}^{\prime} \mathrm{c} 25 \mathrm{MPa}$ is written with the symbol f'c25 Normal

b. Addition SF into the concrete mixtures with a composition is $5 \% \mathrm{SF}$ is written with the symbol f'c25-SF5\%, addition of SF $10 \%$ is written with the symbol $\mathrm{f}^{\prime} \mathrm{c} 25+\mathrm{SF} 10 \%$, addition of SF $15 \%$ to is written with the symbol $\mathrm{f}^{\prime} \mathrm{c} 25+\mathrm{SF} 15 \%$,

c. Addition FA into the concrete mixtures with a composition of $10 \%$ FA is written with the symbol f'c $25+$ FA $10 \%$, Addition of $15 \%$ is written $f^{\prime} \mathrm{c} 25+\mathrm{FA} 15 \%$, and Addition of $20 \%$ is written f'c $25+$ FA20\%

d. Addition of Coca-Cola into the concrete mixtures with a composition is $0.1 \%$ is written with the symbol f'c $25+$ Cola $0.10 \%$, addition of Coca-Cola by $0.15 \%$ is written $\mathrm{f}^{\prime} \mathrm{c} 25+\mathrm{Cola} 0.15 \%$ and for addition of Coca-Cola by $0.2 \%$ is written $\mathrm{f}^{\prime} \mathrm{c} 25+0.2 \%$

e. Specifically for the addition of Plastocrete ${ }^{\circledR}$ RT6 plus, no variations were made but the addition refers to the maximum value of Plastocrete ${ }^{\circledR}$ RT6plus added by the manufacturer [25] which is $0.6 \%$ and written with the symbol f'25+ Plasto $0.6 \%$.

Variants of additional materials in concrete can be presented in the following table 3 below,

Table 3 Quantity of Admixture that is Added into the Concrete Mixtures

\begin{tabular}{|c|c|c|}
\hline Concrete Mixtures & $\begin{array}{c}\text { Water } \\
\mathbf{K g} / \mathbf{m}^{\mathbf{3}}\end{array}$ & $\begin{array}{c}\text { Admixture } \\
\mathbf{K g} / \mathbf{m}^{\mathbf{3}}\end{array}$ \\
\hline f'c25-Normal (control) & 205 & - \\
\hline f'c25+SF5\% & 205 & 22,78 \\
\hline f'c25+SF10\% & 205 & 45,56 \\
\hline f'c25+SF15\% & 205 & 68,34 \\
\hline f'c25+FA10\% & 205 & 45,56 \\
\hline f'c25+FA15\% & 205 & 68,34 \\
\hline f'c25+FA20\% & 205 & 91,12 \\
\hline F'c25+Cola0.1\% & 205 & 0,46 \\
\hline F'c25+Cola0.15\% & 205 & 0,68 \\
\hline F'c25+Cola0.2\% & 205 & 0,91 \\
\hline F'c25+Plas0.6\% & 205 & 2,73 \\
\hline
\end{tabular}

Meanwhile, the effect of concrete's compressive strength test due to the addition of added materials using Coca-Cola and plastocrete ${ }^{\circledR}$ RT6 plus was carried out on two different compressive strengths, namely f'c20 MPa and f'c25 MPa, each of which was then given the symbol f'c20-Normal for concrete f'c20 MPa Normal and f'c25-Normal for f'c25 MPa normal, then another symbol to the addition of added material to each concrete quality can be described as follows:

a. Addition of $0.2 \%$ Coca-Cola to both concrete qualities each given a symbol f'c $20+$ Cola $0.2 \%$ and f'c $25+$ Cola $0.2 \%$

b. Addition of $0.2 \%$ Plastocrete ${ }^{\circledR}$ RT6 plus to the two concrete qualities each given a symbol f'c $20+$ Plast $0.2 \%$ and $f^{\prime} c 25+$ plas $0.2 \%$ 
c. The combination of Plastocrete ${ }^{\circledR}$ RT6 plus Coca-Cola in both concrete qualities each given a symbol f'c20 + Plas $0.35 \%+$ Cola0.15\% (Mix) and f'c25 + Plas $0.35 \%+$ Cola0.15\% (Mix)

d. And for the reduction of the amount of cement used, this study only tries to test the quality of the f'c 25 concrete that named f'c $25+$ Mix-where the reduction of cement is reduced is $11 \%$

The composition of making concrete mixtures with various variations of additional ingredients was made based on the job mix design as presented in table 2 before, where additional ingredients were given based on the percentage of the cement weight, while the reduction in the amount of water used was done on the concrete mixtures that has Coca-Cola and plastocrete®RT6 plus in it, simultaneously. The full details are presented in table 4 below.

Table 4 Water use composition for the addition of Coca-Cola and Plastocrete ${ }^{\circledR}$ RT6 in The Concrete Mixtures

\begin{tabular}{|c|c|c|c|c|}
\hline Concrete Mixtures & $\begin{array}{c}\text { Water } \\
\mathrm{Kg} / \mathrm{m}^{3}\end{array}$ & $\begin{array}{c}\text { Cement } \\
\mathrm{Kg} / \mathrm{m}^{3}\end{array}$ & $\begin{array}{c}\text { RT6plus } \\
\mathrm{Kg} / \mathrm{m}^{3}\end{array}$ & $\begin{array}{c}\text { Cola } \\
\mathrm{Kg} / \mathrm{m}^{3}\end{array}$ \\
\hline f'c20-Normal (control) & 205 & 338,40 & - & - \\
\hline f'c20+Cola0.2\% & 205 & 338,40 & - & 0,65 \\
\hline f'c20+Plas0.2\% & 205 & 338,40 & 0,65 & - \\
\hline f'c20+ Plas0.35\%+ Cola0.15\% (Mix) & 200 & 338,40 & 1,14 & 0,49 \\
\hline f'c25-Normal (control) & 205 & 455,60 & - & - \\
\hline f'c25+Cola0.2\% & 205 & 455,60 & - & 0,91 \\
\hline f'c25+Plas0.2\% & 205 & 455,60 & 0,91 & - \\
\hline f'c25+Plas0.35\%+Cola0.15\% (Mix) & 200 & 455,60 & 1,59 & 0,68 \\
\hline f'c25+Mix Reduced Cement 11\% & 200 & 405,48 & 1,59 & 0,68 \\
\hline
\end{tabular}

\section{RESULTS AND DISCUSSION}

\subsection{The general effect of Admixture}

Figure 2 shows that the concrete setting time that is plotted against penetration resistance measured for 16 hours starting from the initial set taken that is needle penetration to $3.5 \mathrm{MPa}$ (500 Psi) until the concrete needle penetration reaches $27.6 \mathrm{MPa}$ (4000Psi) where the concrete has experienced the final set

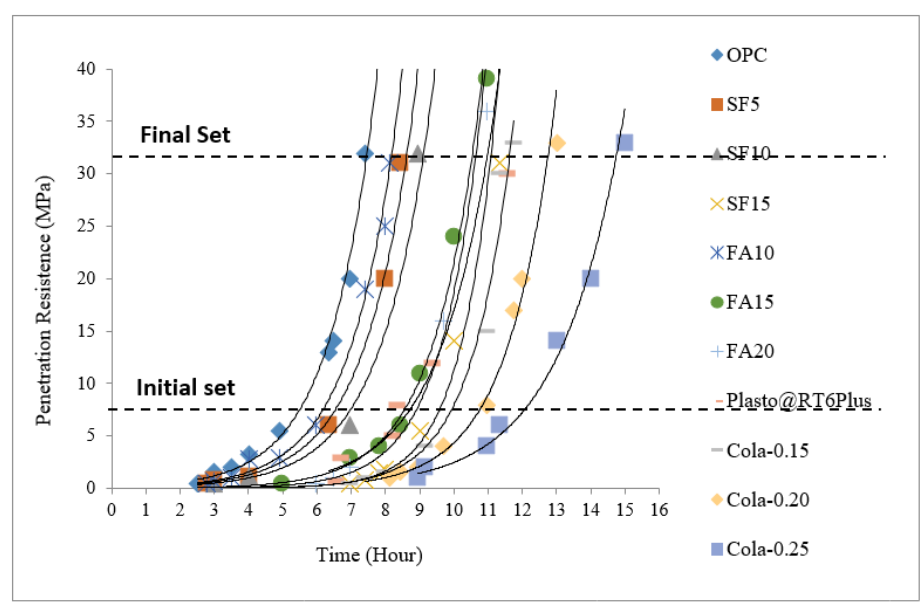

Figure 2 Influence of SF and FA on the resistance of concrete

In general, the image setting model as in Figure 2 above resembles an exponential graphic pattern, this model is in line with previous findings from Polivka and Klein [20] 
The Effect of Combination Additive Admixtures to Increase Setting Time and Compressive Strength at The Concrete Casting in Warm Tropical Temperature

who tested with SF and FA added ingredients. Setting time and slump values during the study are presented in Table 5 below,

Table 5 Effect of Admixture Additive at The Concrete Mixtures in Setting Time and The Concrete Slump Value

\begin{tabular}{|c|c|c|c|}
\hline Concrete Mixtures & $\begin{array}{c}\text { Initial Set } \\
\text { (SA)(h) }\end{array}$ & $\begin{array}{c}\text { Final set } \\
\text { (FS)(h) }\end{array}$ & $\begin{array}{c}\text { Slump } \\
\text { mm }\end{array}$ \\
\hline f'c25-Normal (Control) & 4,9 & 7,6 & 120 \\
\hline f'c25+SF5\% & 6,35 & 8,45 & 115 \\
\hline f'c25+SF10\% & 6,95 & 8,95 & 110 \\
\hline f'c25+SF15\% & 9,01 & 11,35 & 100 \\
\hline f'c25+FA10\% & 5,97 & 8,15 & 112 \\
\hline f'c25+FA15\% & 6,25 & 9,15 & 101 \\
\hline f'c25+FA20\% & 7,1 & 9,75 & 96 \\
\hline F'c25+Cola0.1\% & 9,7 & 11,8 & 123 \\
\hline F'c25+Cola0.15\% & 10,7 & 13,1 & 127 \\
\hline F'c25+Cola0.2\% & 12,2 & 14,85 & 130 \\
\hline F'c25+Plas0.6\% & 7,8 & 11,2 & 135 \\
\hline
\end{tabular}

Table 5 shows the setting time and slump value in the concrete, after adding the added ingredients to the concrete mixtures, It is known that although concrete mix uses the same amount of water, the results show different slump values due to various additives, where the value of the slump in concrete with the addition of minerals will make the water in the concrete absorbed by the mineral added material. while the slump value in the addition of liquid added ingredients has increased because the water in the concrete is absorbed by the mineral addition, while the liquid additional material will cause the to increase water content in the concrete. Thus, it can be said that the largest setting time is indicated by the addition of $0.2 \%$ Coca-Cola which increased by around $14.8 \%$ compared to normal concrete. This value is above the SF, FA and Plstocrete ${ }^{\circledR}$ RT6 plus setting time, thus the Coca-Cola can be said to be a material that can delay concrete setting time, but it still needs to be checked whether Coca-Cola grading can affect concrete quality, based on those facts, this research examine the effect of CocaCola for on concrete quality. At the same time testing it by combining plastocrete $\AA$ RT6 plus Coca-Cola with added levels of $0.35 \%$ plastocrete®RT6plus and Cola-cola by $0.15 \%$, in this study we also tried to reduce the amount of cement in the concrete mixtures [19]. In general, materials used are to slow down the setting time of concrete containing $\mathrm{C} 3 \mathrm{~A}$ compounds that react with tricalcium silicate $(\mathrm{C} 3 \mathrm{~S})$, where these compounds will close the surface of cement particles and slow down the bonding $[19,22]$, as well as in Coca-Cola, where the sugar contained in Coca-Cola will slow the bonding of the cement. [24].

\subsection{The Effect of Coca-Cola and Plastocrete®RT6plus admixture in Concrete Slump Value}

Furthermore, the value of slump in the concrete mix by adding Coca-Cola and Plastocrete ${ }^{\circledR}$ RT6 plus are shown in table 6 below. 
Table 6 Concrete Slump Value

\begin{tabular}{|c|c|c|c|c|c|}
\hline Concrete Mixtures & $\begin{array}{c}\text { Water } \\
\mathrm{Kg} / \mathrm{m}^{3}\end{array}$ & $\begin{array}{c}\text { Water } \\
(\%)\end{array}$ & $\begin{array}{c}\text { RT6 plus } \\
\mathrm{Kg} / \mathrm{m}^{3}\end{array}$ & $\begin{array}{c}\text { Cola } \\
\mathrm{Kg} / \mathrm{m}^{3}\end{array}$ & $\begin{array}{c}\text { Slump } \\
\mathrm{mm}\end{array}$ \\
\hline f'c20-Normal (Control) & 205 & - & - & - & 120 \\
\hline f'c20+Cola 0.2\% & 205 & - & - & 0,65 & 125 \\
\hline f'c20+Plas 0.2\% & 205 & - & 0,65 & - & 126 \\
\hline f'c20+Plas0.35\%+ Cola0.15\% (Mix) & 200 & 2,44 & 1,14 & 0,49 & 130 \\
\hline f'c25-Normal (Control) & 205 & - & - & - & 120 \\
\hline f'c25+Cola 0.2\% & 205 & - & - & 0,91 & 125 \\
\hline f'c25+Plas 0.2\% & 205 & - & 0,91 & - & 126 \\
\hline f'c25+Plas 0.35\%+Cola0.15\% (Mix) & 200 & 2,44 & 1,59 & 0,68 & 130 \\
\hline f'c25+Mix Reduced Cement 11\% & 200 & 2,44 & 1,59 & 0,68 & 131 \\
\hline
\end{tabular}

Table 6 shows that the reduction amount of water at the combination of the f'c $20+$ plas $0.35 \%+$ Cola $0.15 \%, f^{\prime} \mathrm{c} 25+$ plas $0.35 \%+$ Cola $0.15 \%$ and f'c $25+$ M-Reduced Cement, apparently did not affect the slump value because the added ingredients given are liquid, this phenomenon is in line with research conducted by Sri Umniati et al [21], where the additional material will replace the water/cement ratio in the concrete mixtures. The ingredients' effect of adding are presented in Table 7 below:

Table 7 Setting time of Concrete Containing of Coca-Cola and Plactocret巴 RT6 Plus

\begin{tabular}{|c|c|c|}
\hline Concrete Mixtures & $\begin{array}{c}\text { Initial Set } \\
\text { (SA)(h) }\end{array}$ & $\begin{array}{c}\text { Final set } \\
\text { (FS)(h) }\end{array}$ \\
\hline f'c20-Normal (control) & 4,90 & 7,60 \\
\hline f'c20+Cola0.2\% & 12,1 & 14,8 \\
\hline f'c20+Plas0.2\% & 6,65 & 10,8 \\
\hline f'c20+ Plas0.35\%+ Cola0.15\% (Mix) & 6,93 & 10,21 \\
\hline f'c25-Normal (control) & 4,90 & 7,50 \\
\hline f'c25+Cola0.2\% & 6,25 & 14,85 \\
\hline f'c25+Plas0.2\% & 6,63 & 10,65 \\
\hline f'c25+Plas0.35\%+Cola0.15\% (Mix) & 6,87 & 10,19 \\
\hline f'c25+Mix Reduced Cement 11\% & 7,52 & 11,75 \\
\hline
\end{tabular}

Table 7 shows that the water reduction of $2.44 \%$ in (f'c $20+$ plas $0.35 \%+$ Cola $0.15 \%$ ) and (f'c $25+$ plas $0.35 \%+$ Cola $0.15 \%$ ) combination did not affect setting time, even the addition of Coca-Cola by $0.2 \%$ was the longest time of concrete experienced setting time, but the addition of Coca-Cola by $2 \%$ reduced the concrete setting time as the prominent reason to choose reduce the addition of Coca-Cola by $0.15 \%$ in the combination of the added ingredients between Coca-Cola and Plastocrete ${ }^{\circledR}$ RT6 plus, the overall results are presented in Figure 3 below

\subsection{Effect of Coca-Cola and Plastocrete ${ }^{\circledR}$ RT6 plus on Concrete Compressive Strength}

The concrete compressive strength test is conducted based on ASTM C39-86 standard [30], and comparison of concrete compressive strength test's results with a combination of Coca-Cola and Plastocrete ${ }^{\circledR}$ RT6 plus on f'c20 and f'c25 concrete are shown in table 8 , figure 3 , and figure 4 below: 
The Effect of Combination Additive Admixtures to Increase Setting Time and Compressive Strength at The Concrete Casting in Warm Tropical Temperature

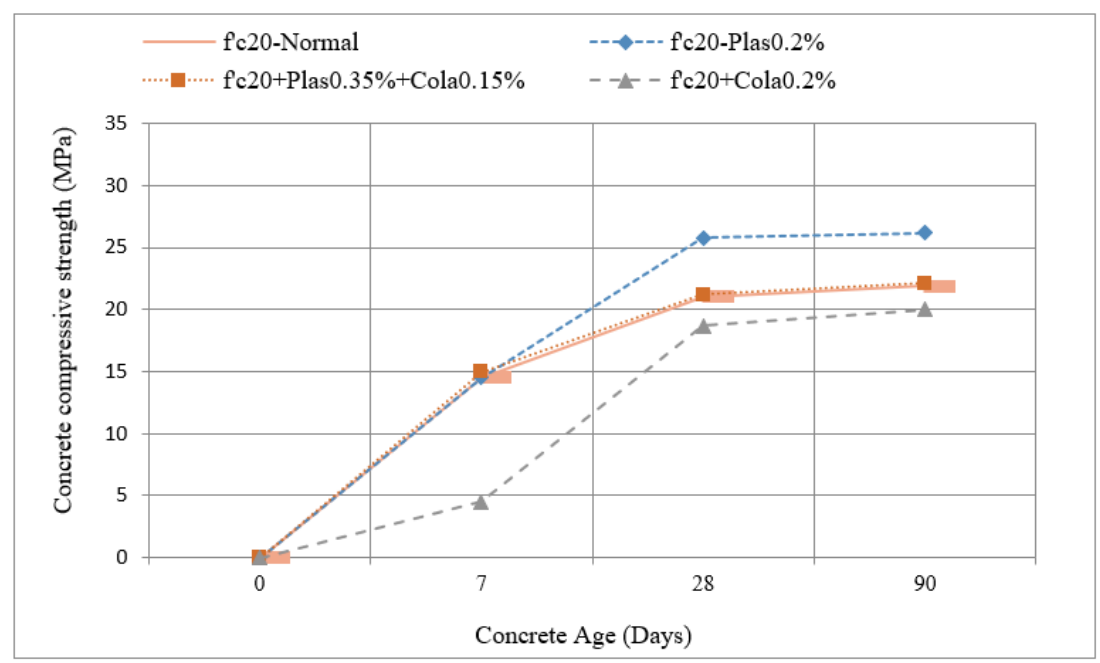

Figure 3 Relationship of concrete age and compressive strength at f'c20 MPa

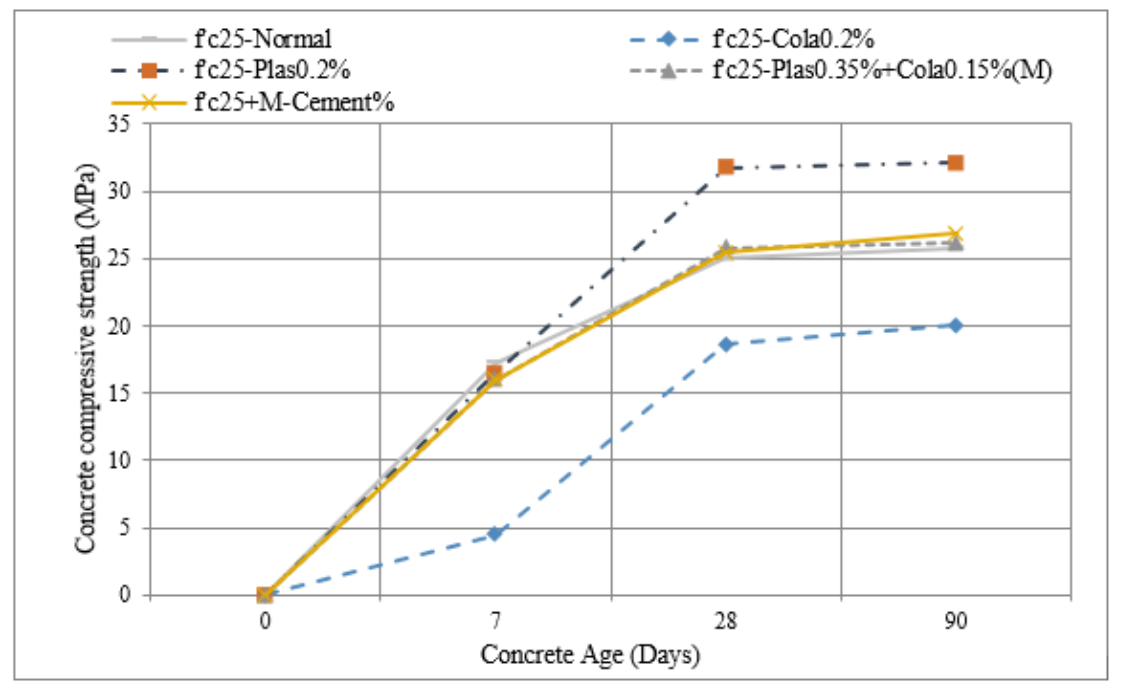

Figure 4 Concrete age relationship with compressive strength at f'c25 $\mathrm{MPa}$

Figures 3 and 4 in the case of the Coca-Cola addition by $0.2 \%$ turn out that the compressive strength of concrete of 28 days is not met, even though the setting time is longer than other concrete mixtures because the sugar content derived from Coca-Cola is damaging the concrete quality. Subsequently, the excessive addition of additional material in the concrete mixtures gives an adverse effect on concrete, therefore, producers tend to provide a maximum limit for the use of allowable additional ingredients as indicated by the manual book Plastocrete ${ }^{\circledR}$ RT6 plus [25]. These results are similar to previous studies, which were conducted by Usman [26]. In the case of adding the ingredients with a combination of Coca-Cola and Plactocrete $\AA$ RT6 plus, the variation of $\mathrm{f}^{\prime} \mathrm{c} 20+$ Plas $0.35 \%+$ Cola $0.15 \%$ and $\mathrm{f}^{\prime} \mathrm{c} 25+\mathrm{Plas} 0.35 \%+$ Cola0 $0.15 \%$ show that the concrete compressive strength is greater than the compressive strength of the plan at the age of 28 days of concrete. Plactocret ${ }^{\circledR}$ RT6 Plus adds a tendency to increase the compressive strength of concrete so that the addition of Plactocret@ RT6 Plus to concrete mixtures can be used to reduce the cement used in concrete as shown in the composition $\mathrm{f}^{\prime} \mathrm{c} 25+\mathrm{M}$-Reduced $11 \%$, where the compressive strength is also still fulfilled even though the use of cement has been reduced by around $11 \%$ 
Table 8 Relative Compressive Strength Concrete Contain Coca-Cola and Plastocrete $® R T 6$ Plus

\begin{tabular}{|c|c|c|c|c|}
\hline Concrete Mixtures & $\begin{array}{c}\text { Cement } \\
\mathbf{K g} / \mathbf{m}^{\mathbf{3}}\end{array}$ & $\begin{array}{c}\text { Reduced } \\
\text { of Cement } \\
(\mathbf{\%})\end{array}$ & $\begin{array}{c}\text { Strength } \\
\text { MPa 28 } \\
\text { Days }\end{array}$ & $\begin{array}{c}\text { Relative } \\
\text { Strength }\end{array}$ \\
\hline f'c20-Normal (control) & 338,4 & - & 21,02 & 1,05 \\
\hline f'c20+Cola0.2\% & 338,4 & - & 18,7 & 0,94 \\
\hline f'c20+Plas0.2\% & 338,4 & - & 25,8 & 1,29 \\
\hline f'c20+ Plas0.35\%+ Cola0.15\% (Mix) & 338,4 & - & 22,1 & 1,11 \\
\hline f'c25-Normal (control) & 455,6 & - & 25,03 & 1,00 \\
\hline f'c25+Cola0.2\% & 455,6 & - & 18,7 & 0,75 \\
\hline f'c25+Plas0.2\% & 455,6 & - & 31,75 & 1,02 \\
\hline f'c25+Plas0.35\%+Cola0.15\% (Mix) & 455,6 & - & 25,78 & 1,27 \\
\hline f'c25+Mix Reduced Cement 11\% & 450,48 & 11 & 26,85 & 1,02 \\
\hline
\end{tabular}

Table 8 shows the relative compressive strength of the materials added to the concrete mix for several variations including the addition of materials.

a. The addition of $0.2 \%$ Coca-Cola into the concrete mixtures made the compressive strength of the concrete not fulfilled at 28 days

b. Addition of Coca-Cola and Plactocret ${ }^{\circledR}$ RT6 Plus with variations of f'c $20+$ Plas $0.35 \%+$ Cola0 $.15 \%(\mathrm{M})$ and $\mathrm{f}^{\prime} \mathrm{c} 25+$ Plas $0.35 \%+$ Cola0 $.15 \%(\mathrm{M})$, compressive strength plan at 28 days exceed $1.27 \%$ for f'c20 and $1.29 \%$ for f'c25.

c. The addition of additional materials with the symbol f'c25 + M-Reduced Cement shows that the compressive strength of concrete can be achieved of 28 days.

Excessive addition of Coca-Cola in concrete can increase the concrete setting time but decreases the concrete's compressive strength is due to the excessive amount of sugar in the concrete interferes the bonding of the cement, therefore the maximum limit of using Coca-Cola to delay setting time is $0,15 \%$ of the weight of the cement used in concrete, these results are similar to studies, which were conducted by Usman [26]. The concrete compressive strength in the variation of added material f'c $25+$ M-Reduced Cement can be a solution to reduce the cement used in a construction project.

The result shows that the addition of Coca-Cola and Plastocrete ${ }^{\circledR}$ RT6 plus is not only to provide an optimal delay effect on concrete setting time but also significantly increases the compressive strength of concrete. Thus, utilizing the properties can be the basis to reduce the cement used up to $11 \%$. This material has overcome several problems in casting the construction of Mulawarman University building, Samarinda, Indonesia, where casting is frequently done in the warm tropical weather.

\section{CONCLUSION}

Based on the results of the discussions that have been carried out above, it can be concluded as follows:

1. The setting time that occurs in all concretes, whether with added additive or not, tends to follow an exponential function.

2. The use of Coca-Cola in adding a concrete setting time can be done with a limit of $0.15 \%$ from cement weight and the amount should be adjusted based on how long the setting time delay is needed.

3. Adding the additional material to the concrete in the form of a combination of Plastocrete ${ }^{\circledR}$ RT6 plus Coca-Cola, it can delay the setting time and increases 
The Effect of Combination Additive Admixtures to Increase Setting Time and Compressive Strength at The Concrete Casting in Warm Tropical Temperature

the compressive strength of the concrete. In certain compositions, such as the variation of $f^{\prime} c 25+$ Mix can reduce cement until $11 \%$ without affecting the compressive strength of concrete.

\section{ACKNOWLEDGMENT}

This research is fully supported by the Project Implementation Unit (PIU) 4 In One, IDB Mulawarman University-Indonesia.

\section{REFERENCES}

[1] Aitcin PC. High-performance concrete. E \& FN Spon 1998:591.

[2] Caldarone MA, Gruber KA, Burg RG. High-reactivity metakaolin: A new generation mineral admixture. Concrete lnt November 1994:3740.

[3] Japan Concrete Institute. Test method for autogenous shrinkage and autogenous expansion of cement paste, mortar, and concrete. In Proceedings of the International Workshop on Autogenous Shrinkage of Concrete, Hiroshima, Japan, 13-14 June 1998; pp. 58-61.

[4] Mehta PK, Monteiro PJM, Concrete structures, properties, and materials. Englewood Cliffs, NJ: Prentice-Hall, 1993. p. 334-336.

[5] Kruml F. Setting process of concrete. In: Wierig H-J, editor. Properties of fresh concrete, Proceedings of the RILEM Colloquim, Hanover: Chapman \& Hall, 1990. p. $10-16$.

[6] Eren 0, Brooks JJ, Celik T. Setting of fly ash and slag-cement concrete as affected by curing temperature. Cement, Concrete, and Aggregates 1995;17(1):1 1-7.

[7] Naik TR, Singh SS. Influence of fly ash on setting and hardening characteristics of concrete systems. AC1 Mater J 1997;94(5):355-360.

[8] Naik TR, Ramme BW. Effects of high-lime fly ash on water demand, time of set, and compressive strength of concrete. AC1 Mater J 1990;87(6):619-626.

[9] Hogan FJ, Meusel JW. Evaluation for durability and strength development of a ground granulated blast furnace slag. Cement, Concrete Aggregates 1981;3(1):4052.

[10] Sivasundaram V, Carett GG, Malhotra VM. Properties of concrete incorporating a low quantity of cement and the high volume of low-calcium fly ash. In: Malhotra VM, editor. Proceedings of Third International Conference on Fly Ash, Silica Fume, Slag, and Natural Pozzolans in Concrete, Trondheim, Norway, AC1 SP 114, vol. 1. 1989. p. 45-72.

[11] Tazawa Y, Ohomoto T, Taira K. Properties of anti-washout concrete with high blast-furnace slag content, In Malhotra VM, editor. Proceedings of Third International Conference on Fly Ash, Silica Fume, Slag, and Natural Pozzolans in Concrete, Trondheim, Norway, AC1 SP 114, vol. 2. 1989. p. 1615-1636.

[12] Khedr SA, Abou-Zeid MN. Characteristics of silica-fume concrete. J Mater Civil Eng 1994;6(3):357-75.

[13] Alshamsi AM, Alhosani Kl, Yousri KM. Hydrophobic materials, superplasticizer and micro-silica effects on setting of cement paste at various temperatures. Magazine Concrete Res 1997;49(179):11 1-5.

[14] Alshamsi AM, Sabouni AR, Bushlaibi AH. Influence of set retarding superplasticizers and micro silica on setting times of pastes at various temperatures. Cement Concrete Res 1993;23:592-8

[15] Pistilli MF, Wintersteen R, Lechner R. The uniformity and influence of silica fume from a U.S. source on the properties of Portland cement concrete. Cement, Concrete Aggregates 1984;6(2): 120-4. 
[16] De Almeida IR, Goncalves AF. Properties of freshly mixed high-strength concrete. In: Wierig, H-J, editor. Properties of fresh concrete, Proceedings of the RILEM Colloquim, Hanover, Chapman \& Hall, 1990. p. 227-234.

[17] Malhotra VM, Mehta PK. Pozzolanic and cementitious materials. Advances in concrete technology, vol. 1. London: Gordon and Breach, 1996. p. 191.

[18] J.J. Brooks, M.A. Megat Johari, M. Mazloom. Effect of admixtures on the setting times of high-strength concrete, Cement \& Concrete Composites 22 (2000) 293301

[19] ASTM C 403/C 403/M. Standard Test Method for Time of Setting of Concrete Mixture by Penetration Resistance. American Society for Testing and Materials, 1995. p. 217-221.

[20] Polivka M, Klein A. Symposium on the effect of water-reducing admixture on properties of concrete. ASTM STP 266, American Society for Testing Materials, Philadelphia, 1960. p. 124-149.

[21] B. Sri Umniati, Puput Risdanareni, Fahmi Tarmizi Zulfikar Zein.Workability Enhancement of Geopolymer Concrete through The Use of Retarder, AIP Conference Proceedings 1887, 020033 (2017); DOI: 10.1063/1.5003516

[22] Singh NB, Singh AK. Effect of the element on the hydration of white Portland cement. Cement Concrete Res 1989;19:547-753.

[23] ASTM C 33-92, Standard Specification for Concrete Aggregate, ASTM Book of Standards, Part 04.02, ASTM, West Conshohocken, PA, 7 pp.

[24] Wadhah M. Tawfeeq, Ahmed Al-Shibli, Mohammed Al-Jarwani, and Othman AlZakwani.Slump and Compressive Strength of Concrete Mix with Crushed Concrete Blocks as Coarse Aggregate. International Journal of Advanced Engineering and Management Research, 2016 p.498-509

[25] Technical Data Sheet, Plastocrete ${ }^{\circledR}$ RT6 Plus Water Reducing and Set Retarding 2017

[26] Usman, N.D.; Chom, H.A.; Salisu, C.; Abubakar, H.O.; Gyang, J.B. The Impact of Sugar on Setting -Time of Ordinary Portland Cement (OPC) Paste and Compressive Strength of Concrete. FUTY J. Environ. 2016, 10, 107-144.

[27] Emily E.V.; Jaimie N. D.; Michael I.Goran. Sugar Content of Popular Sweetened Beverages Based on Objective Laboratory Analysis: Focus on Fructose Content, Methods, and techniques. 2010, 10,1-7

[28] D. Bhunia, S.B. Singh and A. Imam, A Study on Effect of Carbonation on the Properties of Concrete. Birla Institute of Technology \& Science, Pilani. 2016

[29] ASTM C 403/C 403M - 99 Standart Test Method for Time of Setting of Concrete Mixtures by Penetration Resistance, Annual Books of ASTM Standards, USA, 2002.

[30] ASTM C39-86 Standard Test Method for Compressive Strength of Cylindrical Concrete Specimens, ASTM International, West Conshohocken, PA. 2002

[31] American Concrete Institut, ACI 318-89 Building Code Requirements for Reinforced Concrete, Part I, General Requirements, Fifth Edition, Skokie, Illinois, USA: PCA, 1990.5pp. 